\title{
PENERAPAN KONSEP ARSITEKTUR REGIONALISME PADA BANGUNAN AULA INSTITUT TEKNOLOGI BANDUNG
}

\author{
Sri Indriani Solehah ${ }^{1}$, Ashadi $^{2}$ \\ ${ }^{1}$ Program Studi Arsitektur, Universitas Muhammadiyah Jakarta \\ 2017460056@ftumj.ac.id \\ ${ }^{2}$ Program Studi Arsitektur, Universitas Muhammadiyah Jakarta \\ ashadi@ftumj.ac.id
}

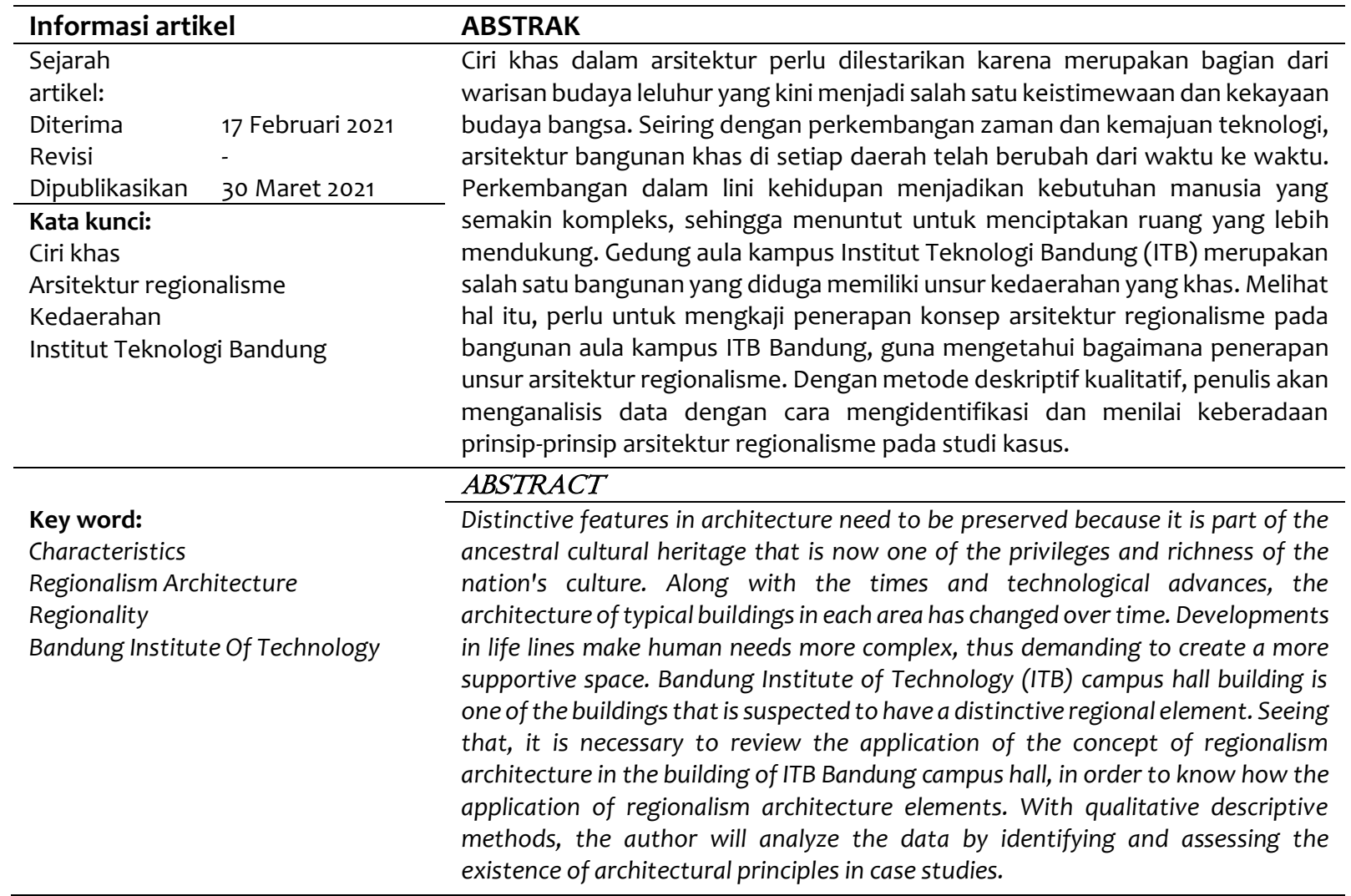

\section{PENDAHULUAN}

Kejenuhan beberapa arsitek dalam rancangan yang bersifat global dan universal serta menyebabkan hilangnya keberagaman dan ciri khas yang dengan ini muncul pergerakan untuk menghidupkan kembali ciri kedaerahan yang disebut arsitektur regionalisme. Regionalisme didefinisikan sebagai suatu kesadaran untuk membuka kekhasan tradisi suatu daerah dalam merespon terhadap tempat dan iklim, kemudian melahirkan identitas formal dan simbolik. Dari uraian singkat tersebut, arsitektur regionalisme merupakan tema arsitektur yang perlu dikaji lebih jauh. Laporan ini bertujuan mengkaji tema arsitektur regionalisme terutama pada bangunan pendidikan.

Studi kasus ini (Bangunan pendidikan) dipilih dengan pertimbangan bahwa selain karena budayanya, pendidikan pun menjadi hal yang sama pentingnya untuk kemajuan suatu negara. Pendidikan merupakan hal yang sangat penting dalam kehidupan manusia, guna menjadi bekal untuk kehidupan yang akan datang terutama pada masa modernisasi saat ini. Pendidikan tinggi dapat membantu suatu negara untuk mencapai kemajuan teknologi melalui inovasi dan adaptasi sehingga dapat menciptakan sumber daya manusia yang terdidik dan terpelajar serta mampu menciptakan kemajuan di segala bidang. 
Dalam artikel ini akan dikaji penerapan konsep arsitektur regionalisme pada bangunan aula kampus Institut Teknologi Bandung (ITB). Gedung aula kampus ITB merupakan salah satu bangunan yang diduga memiliki unsur arsitektur regionalisme. Melihat hal itu, perlu untuk mengkaji penerapan konsep arsitektur regionalisme pada bangunan pendidikan tersebut. Adapun tujuan dilaksanakannya penelitian ini adalah untuk memahami konsep arsitektur regionalisme serta untuk memahami penerapan konsep arsitektur regionalisme pada bangunan pendidikan.

\section{Studi Literatur}

\section{Arsitektur Regionalisme}

Di dalam arsitektur, Regionalisme adalah sebuah perkembangan arsitektur yang memperhatikan terhadap karakteristik regional yang berkaitan erat dengan budaya, iklim dan teknologi pada saat itu, serta perpaduan antara yang lama dengan yang baru dan berharap bangunan yang dihasilkan bersifat lestari (Hidayatun, dkk, 2014).

Mahastuti mengutip Tan Hock Beng, mendefinisikan regionalisme sebagai suatu kesadaran untuk menghidupkan kembali kekhasan tradisi/budaya suatu daerah dalam merespon terhadap tempat dan iklim yang kemudian melahirkan identitas formal dan simbolik.

Berdasarkan beberapa teori tersebut dapat disimpulkan bahwa konsep arsitektur regionalisme akan memperhatikan ciri-ciri kedaerahan, yaitu: arsitektur setempat, iklim, budaya, dan teknologi modern (Shobirin, dkk, 2019)

Istilah regionalisme yang sudah berkembang di bidang arsitektur sering beririsan dengan tradisionalitas dan etnisitas. Walaupun sebenarnya ketiganya memiliki perbedaan. Tradisionalitas menekankan pada norma dan warisan yang diturunkan secara turun-temurun dan kemudian dilakukan dengan cara yang sama. Lalu etnisitas menekankan pada kebudayaan masyarakatnya dari segi memahami makna, simbol, serta kepercayaan yang dianut.

\section{Jenis Arsitektur Regionalisme}

Menurut Suha Ozkan seperti diacu oleh Melisa dan Apritasari, regionalisme telah dibagi menjadi dua bagian yaitu vernacular dan regionalisme modern (Melisa dan Apritasari, 2020). Berikut merupakan gambaran jenis-jenis arsitektur regionalisme.

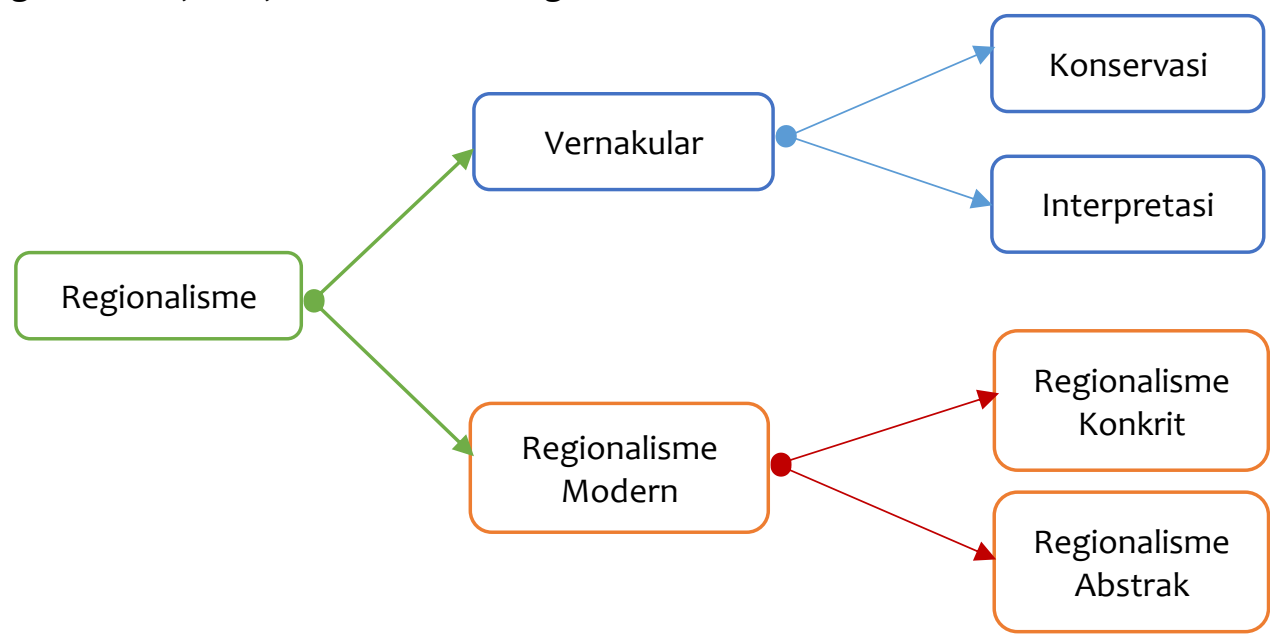

Gambar 1. Jenis Regionalisme

Sumber: Pribadi, 2020

Seperti diacu oleh Melisa dan Apritasari, Ozkan telah membagi regionalisme modern menjadi 2 yaitu antara lain (Melisa dan Apritasari, 2020): 
a. Concrete Regionalisme

Pendekatan dengan aspek ekspresi bangunan arsitektural dengan mengambil elemen-elemen tertentu dengan sarat akan pemaknaan maupun nilai-nilai spiritual.

b. Abstract Regionalisme

Pendekatan yang menekankan pada penggabungan unsur-unsur yang bersifat abstrak pada bangunan seperti pada komposisi massa, pengalaman ruang, fungsi, skala, proporsi, solidvoid, pencahayaan, struktur, dan teknologi yang diolah menjadi bentukan yang baru.

\section{Prinsip Arsitektur Regionalisme}

Terdapat beberapa prinsip pada arsitektur regionalisme, antara lain adalah sebagai berikut.

1. Material menggunakan bahan bangunan lokal dengan teknologi modern

2. Tanggap dalam mengatasi kondisi iklim di daerah setempat

3. Memiliki konteks budaya setempat

Dalam kaitannya dengan lokasi, arsitektur mengangkat kelokalan sebagai bagian penting dari arsitektur, yaitu dengan cara memakai material lokal, alat mekanik lokal, pekerja lokal, memperhatikan kebutuhan lokal, memperhatikan budaya/tradisi/sejarah lokal, sehingga hal tersebut dapat digunakan dalam proses berarsitektur (Rachmawati \&Prijotomo, 2010).

Material atau bahan bangunan merupakan unsur utama dalam perancangan arsitektur. Dalam Frick (1997) dikatakan bahwa bahan bangunan dapat dikategorikan menjadi bahan bangunan alami dan bahan bangunan buatan. Bahan bangunan alami adalah bahan bangunan yang bersifat anorganik, seperti batu alam, tanah liat, dan tras, dan juga yang bersifat organik, seperti daun, kayu, dan bambu. (Octavia, dkk, 2013)

Iklim tropis adalah iklim yang terjadi atau berlaku pada daerah tropis, yakni daerah diantara isotherm 200 dibelahan bumi utara dan selatan. Terdapat dua macam iklim tropis yakni tropis kering dan tropis lembab. Menurut Lippsmeier (1994) Indonesia termasuk dalam daerah hutan hujan tropis atau tropika basah yang meliputi daerah sekitar katulistiwa sampai sekitar 150 utara dan selatan. Karakter iklim tropis lembab ditandai dengan presipitasi (hujan) dan kelembaban tinggi dengan temperatur yang hampir selalu tinggi. Terdapat dua musim dalam tiap tahunnya, yakni musim kemarau dan musim penghujan (Sardjono, 2012).

Kondisi iklim ini akan mempengaruhi rasa nyaman penghuni dalam bertempat tinggal. Dalam upaya mencapai kenyamanan untuk bertempat tinggal, dapat digunakan elemen pendukung untuk mengendalikan kenyamanan termal. Elemen-elemen iklim tropis yang mempengaruhi kenyamanan termal antara lain adalah (Sardjono, 2012):
a. Radiasi
b. Temperatur Udara
c. Kelembaban Udara
d. Curah Hujan
e. Pergerakan Udara

Konteks budaya dalam arsitektur regionalisme merupakan bagian dari hal yang berhubungan dengan kebudayaan. Kebudayaan biasanya dapat berupa konteks sosial, agama, teknologi, estetika, serta kebutuhan lainnya dalam pemenuhan kebutuhan di lingkup daerah tersebut. Dalam arsitektur regionalisme, konteks budaya tercermin dalam wujud karya arsitektur. 


\section{METODOLOGI}

\section{Metode Penelitian}

Metode penelitian yang digunakan yaitu deskriptif kualitatif, dengan bertujuan untuk menggambarkan, mengidentifikasi, dan menganalisis masalah yang diteliti yaitu terkait dengan penerapan konsep arsitektur regionalisme. Pendekatan yang digunakan dalam penelitian ini adalah dengan pendekatan studi kasus. Dengan adanya studi kasus, peneliti dapat lebih mudah mengidentifikasi segala aspek pada objek secara mendalam serta mengetahui bagaimana konsep arsitektur regionalisme.

Dikarenakan saat ini sedang dalam keadaan pandemi, sehingga data yang digunakan yaitu bersumber dari data sekunder. Proses pengumpulan data yaitu dengan cara memaksimalkan penggunaan sumber dari jurnal, buku, atau website yang membahas tentang regionalisme dan konsep arsitektur regionalisme. Lalu mengkaji seluruh pustaka yang telah didapat untuk mendapatkan pemahaman dan inti dari penelitian yang akan dilakukan. Kemudian mencari data sekunder seputar kajian teoritis dan juga studi kasus. Setelah menemukan prinsip-prinsip yang akan digunakan dalam penelitian, dilanjutkan ke tahapan analisis hingga menemukan hasil.

\section{Metode Analisis Data}

Dalam menganalisis data yang telah didapat, penulis mendeskripsikan prinsip-prinsip arsitektur regionalisme yang bersumber dari tinjauan teoritis yang ada pada aspek bangunan studi kasus. Analisis dilakukan dengan cara mengidentifikasi dan menilai keberadaan (ada atau tidaknya) prinsip-prinsip arsitektur regionalisme pada bangunan studi kasus. Dapat dilihat pada gambar 2 di bawah ini.

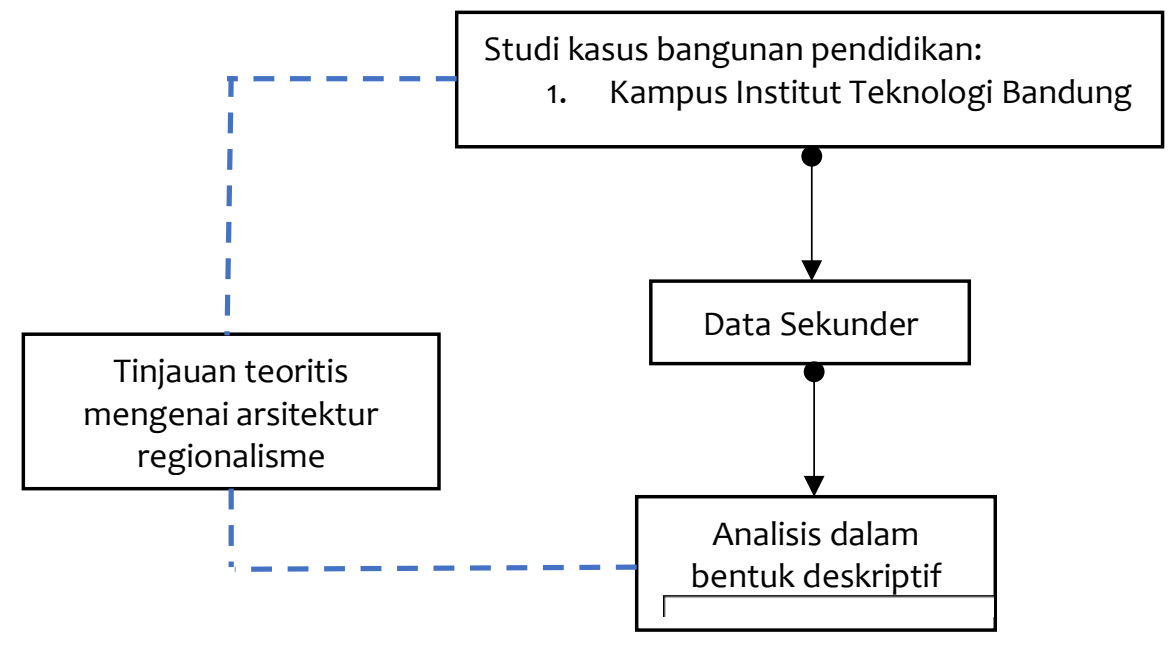

Gambar 2. Teknik Analisis Data

Sumber : Pribadi, 2020

\section{HASIL DAN PEMBAHASAN}

\section{Studi Kasus}

Penelitian ini menggunakan studi kasus bangunan aula kampus Institut Teknologi Bandung (ITB) yang berlokasi di Jl. Ganesha No.10, Lb. Siliwangi, Kecamatan Coblong, Kota Bandung, Jawa Barat. Pertimbangan pemilihan studi kasus antara lain:

- Jenis bangunan studi kasus termasuk ke dalam spesifikasi tema penelitian. 
- Jenis bangunan studi kasus memiliki kekhasan fasad dan bentuk bangunan kedaerahan di nusantara, yang hal ini dapat dianggap merupakan salah satu ciri arsitektur regionalisme

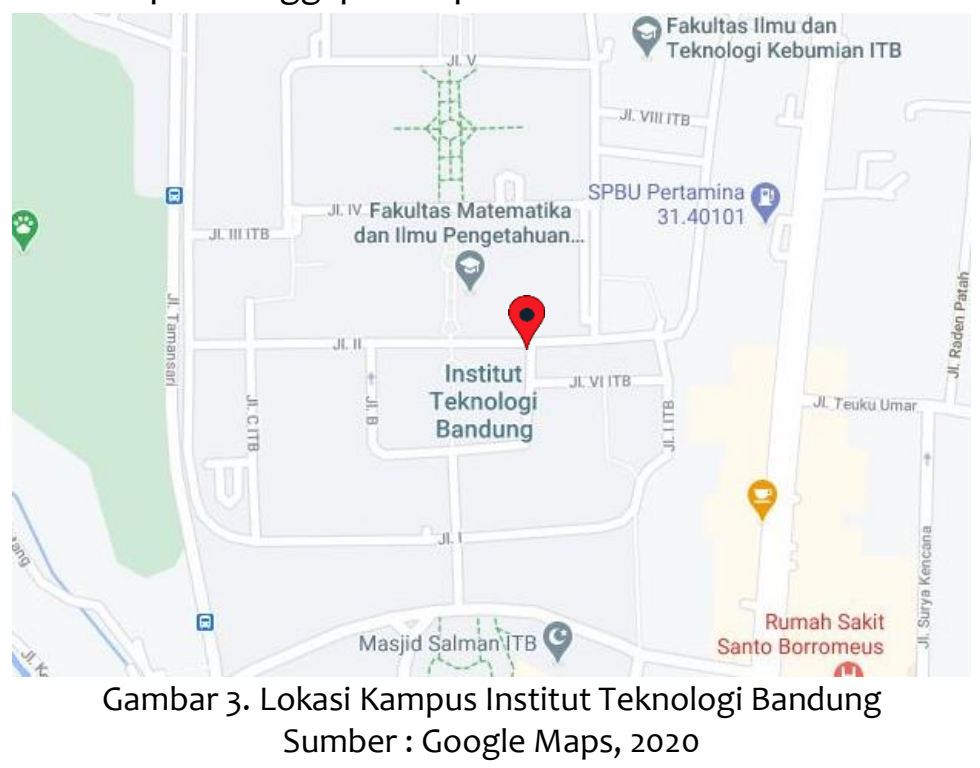

Aula Timur dan Barat atau dahulu dinamakan dengan Barakgebouw B dan Barakgebouw B merupakan gedung pertama yang dibangun di Kampus ITB. Bangunan ini berbentuk memanjang, serta penggunaan atap tradisional khas Jawa Barat sesuai dengan lokasi kampus ITB. Penggunaan bukaan yang banyak pada setiap sisi berfungsi untuk memasukan cahaya alami ke dalam ruangan aula. Bentuk keaslian gedung sampai saat ini tetap dipertahankan sehingga menjadikan sebuah ciri khas lokalitas yang masih melekat.

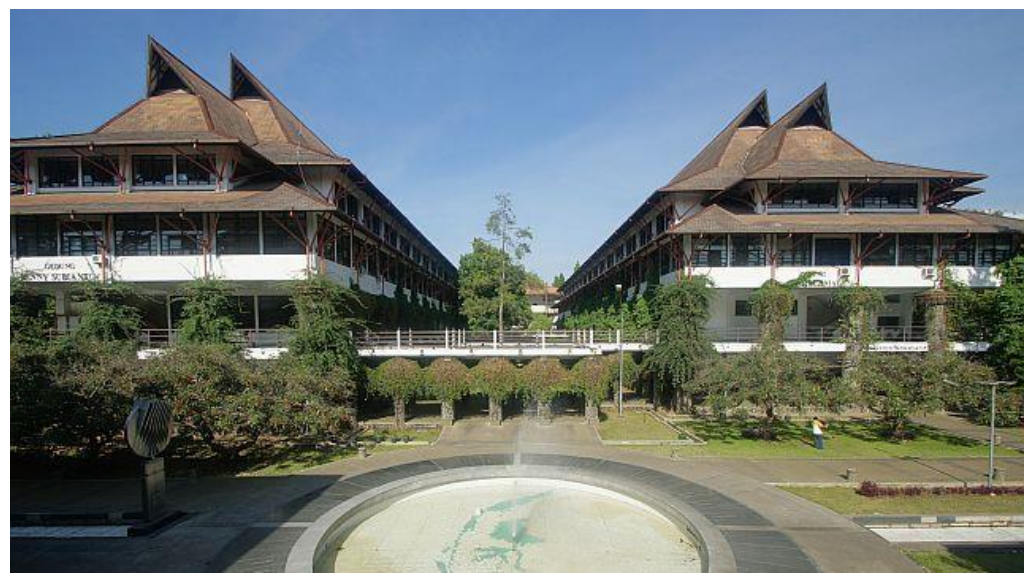

Gambar 4. Tampak Gedung Aula Institut Teknologi Bandung

Sumber: http://www.math.itb.ac.id, 2020

\section{Analisis}

\section{Material Menggunakan Bahan Bangunan Lokal dengan Teknologi Modern}

Material lokal pada umumnya digunakan pada bangunan-bangunan tradisional dengan teknologi yang tradisional. Pada arsitektur regionalisme penggunaan material lokal ditekankan pada penggunaan teknologi modern. Prinsip pertama akan dianalisis dengan cara mengidentifikasi dan menilai penggunaan material lokal yang menggunakan teknologi modern pada ketiga studi kasus. Pada pembahasannya akan dibagi menjadi 3 bagian yaitu antara lain:

1. Kepala Bangunan

2. Badan Bangunan 


\section{Kaki Bangunan}

\section{Kepala Bangunan}

Pada bagian kepala bangunan terdapat bagian atap yang diduga diadaptasi dari atap rumah adat Sunda, yaitu rumah jolopong.. Material atap yang digunakan pada gedung aula ITB ini menggunakan material dari sirap. Atap sirap ini merupakan atap yang berbahan dasar dari kayu ulin. Keunggulan dari penggunaan sirap yaitu dapat menahan hawa panas dari sinar matahari secara maksimal sehingga dapat memberikan efek yang menyejukkan pada bangunan. Daya tahan yang dimiliki atap sirap ini tinggi selain itu pula dapat memberikan kesan yang natural.

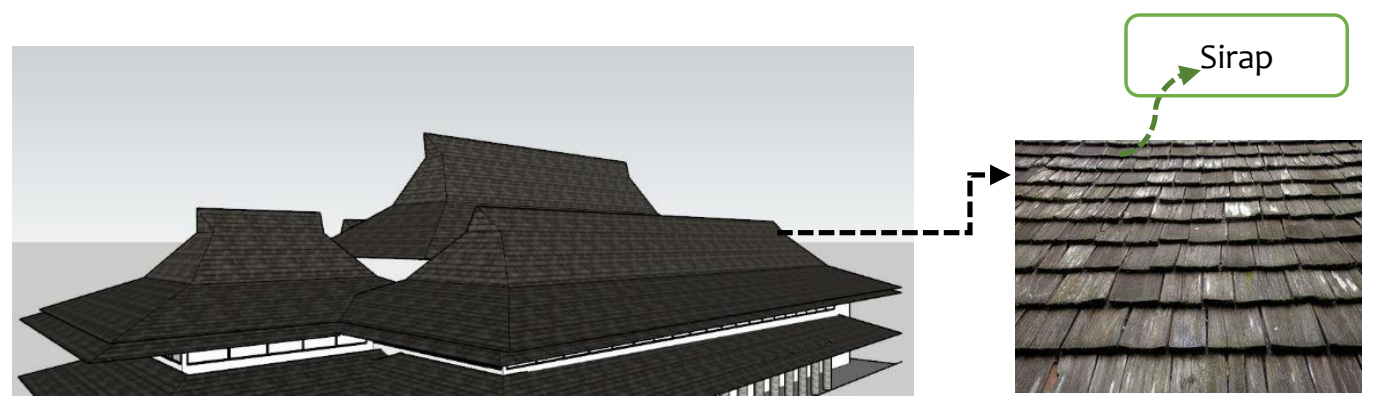

Gambar 5. Material Kepala Bangunan Aula ITB

Sumber: Pribadi, https://arafuru.com, 2020

\section{Badan Bangunan}

Bagian badan bangunan gedung aula ITB ini didominasi oleh tritisan yang ada pada sekeliling bangunan. Material yang digunakan pada tritisan sama dengan atap yaitu dengan sirap kayu ulin. Sedangkan pada bagian dinding bangunan dengan menggunakan material bata dan kayu serta pada bagian sisinya terdapat banyak bukaan. Material tersebut mudah didapat di lingkungan lokal karena merupakan bahan bangunan tradisional. Berikut merupakan gambaran dari material yang digunakan pada bagian badan bangunan.

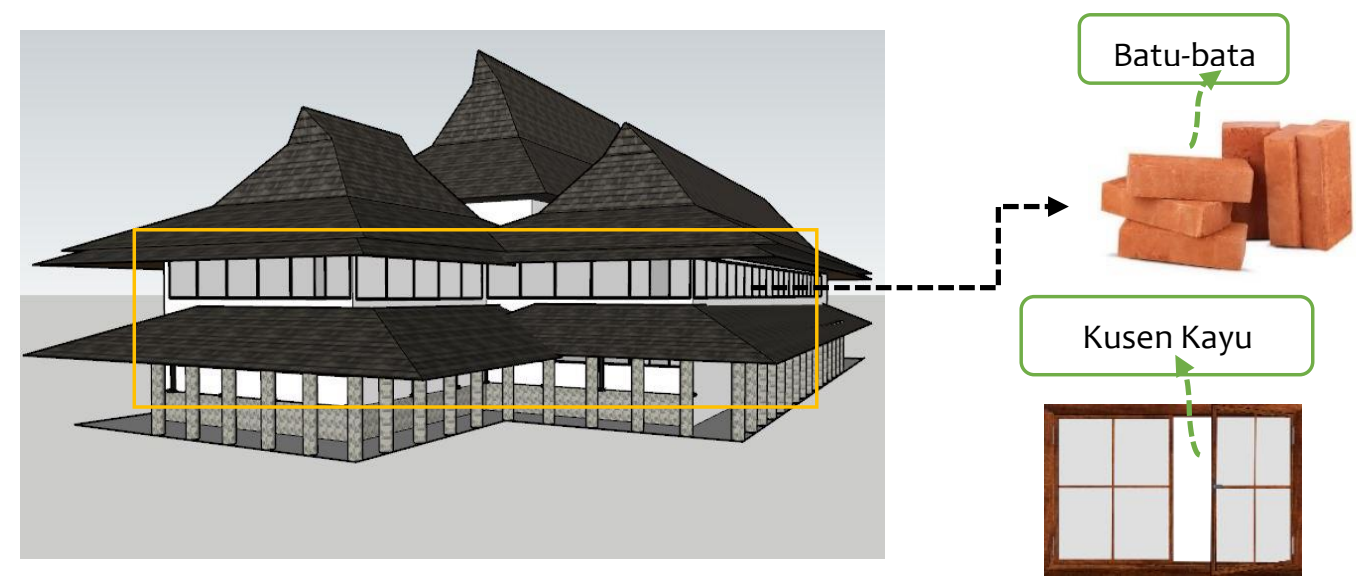

Gambar 6. Material Badan Bangunan Aula ITB

Sumber: Pribadi, https://www.arsigriya.com, 2020

\section{Kaki Bangunan}

Pada bagian kaki, terdapat selasar di sekeliling bangunan yang juga masih ternaungi oleh tritisan dari sirap. Lalu pada setiap sisi selasar terdapat kolom-kolom dengan bahan utama yaitu batu alam yang diplester. Desain yang dibuat yaitu dengan tidak menghilangkan aksen batunya agar tetap 
memberikan nuansa alami. Selain karena biaya produksinya yang tidak sebesar material non lokal, material yang digunakan juga dapat memberikan kesan estetik dan alami pada bangunan.

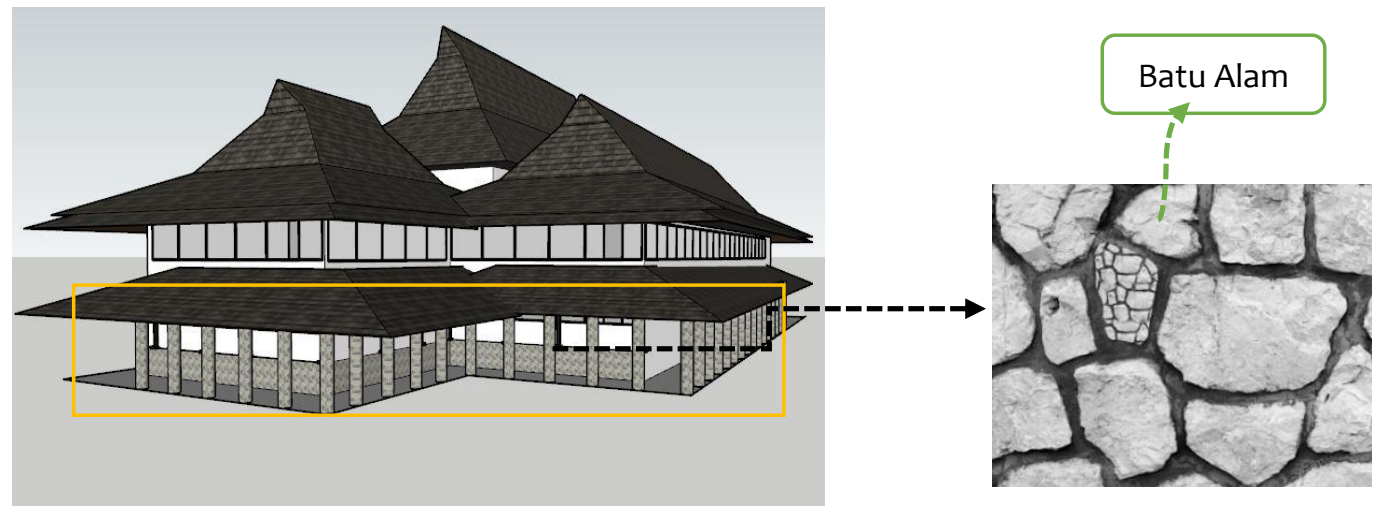

Gambar 7. Material Kaki Bangunan Aula ITB

Sumber: Pribadi, http://jagobangunan.com, 2020

Dapat disimpulkan berdasarkan pembahasan di atas bahwa bangunan ini menggunakan material lokal pada ketiga bagiannya. Sehingga hasilnya dapat dikatakan telah memenuhi prinsip pertama dengan secara keseluruhan.

a) Bagian kepala bangunan menggunakan material lokal

b) Bagian badan bangunan menggunakan material lokal

c) Bagian kaki bangunan menggunakan material lokal

\section{Tanggap Dalam Mengatasi Kondisi Iklim di Daerah Setempat}

Prinsip kedua yaitu “Tanggap Dalam Mengatasi Kondisi Iklim di Daerah Setempat” adalah prinsip yang berisi mengenai bagaimana bangunan dapat berupaya dalam merespon iklim di mana bangunan itu berdiri. Bangunan yang baik adalah yang dapat merespon kondisi iklim di luar seperti radiasi matahari, temperatur udara, curah hujan dan lain sebagainya hingga dapat menjadikan kondisi yang nyaman pada bagian dalamnya. Dilihat dari elemen bangunannya, terdapat 3 kriteria yang akan dibahas pada analisis prinsip tersebut yaitu:

1. Jendela Menjorok Ke Dalam

2. Adanya Tritisan

3. Adanya Ruangan Bebas Dinding (Terbuka)

\section{Jendela Menjorok Ke Dalam}

Letak bukaan terdapat di bagian sisi bangunan dengan posisi yang tidak menjorok ke bagian dalam bangunan. Hal tersebut tentu tidak memenuhi kriteria yang kedua, namun terbantu oleh tritisan yang mendominasi area bukaan tersebut. Tritisan ini hampir menutupi area bukaan yang menjadikan jendela-jendela yang ada menjadi terhindar dari tempias air hujan dan panas matahari. 


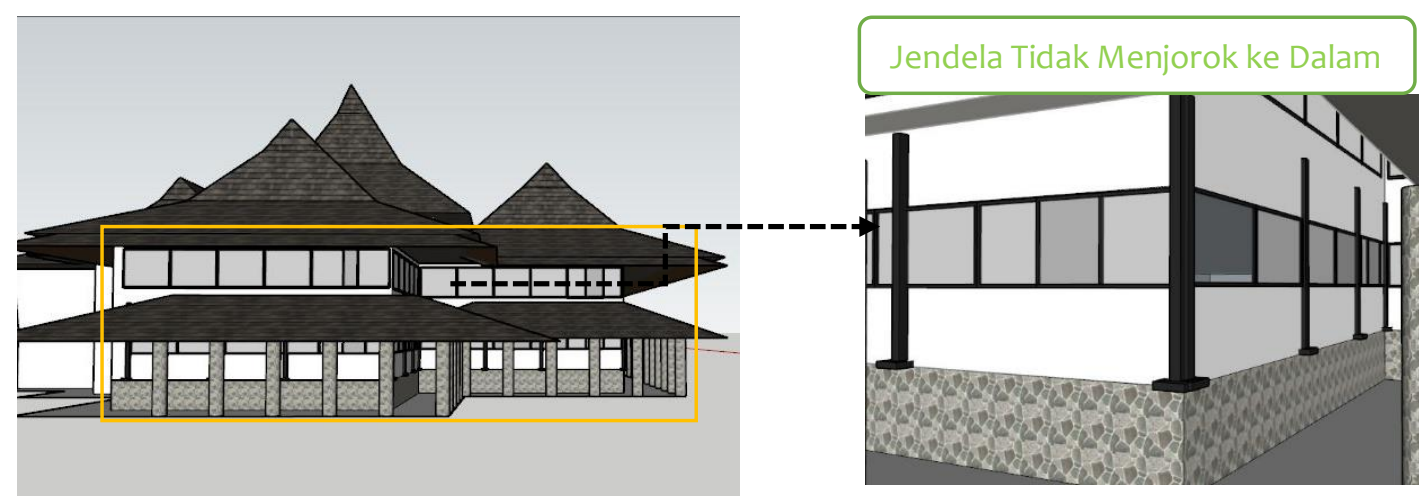

Gambar 8. Fasad Jendela ITB

\section{Adanya Tritisan}

Sumber: Pribadi, 2020

Tritisan pada gedung aula ITB ini terlihat mendominasi bagian badan bangunan. Hal itu terlihat dari adanya lapisan tritisan di sekeliling bangunan yang hampir menutupi bagian bukaan. Namun dengan hal itu, tritisan tersebut dapat menaungi bagian badan bangunan terutama pada area bukaan dan selasar. Sehingga dapat meminimalisir dari dampak iklim tropis seperti panas dan tempias air hujan.

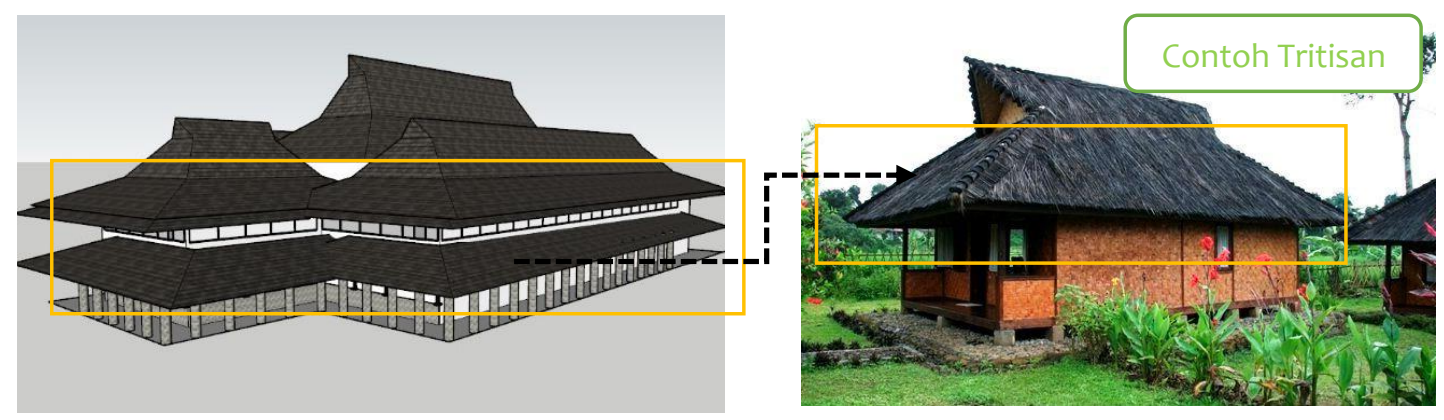

Gambar 9. Tritisan ITB

Sumber: Pribadi, https://edesainminimalis.com, 2020

\section{Adanya Ruangan Bebas Dinding (Terbuka)}

Ruangan terbuka pada gedung aula ITB terdapat pada bagian sisi bangunan yang berupa selasar. Selasar ini tidak memiliki dinding, hanya dikelilingi oleh kolom-kolom sehingga aliran udara dapat masuk dengan mudah dan kemudian dapat memberikan kenyamanan bagi penghuni. Hal tersebut merupakan respon bangunan terhadap angin atau penghawaan.

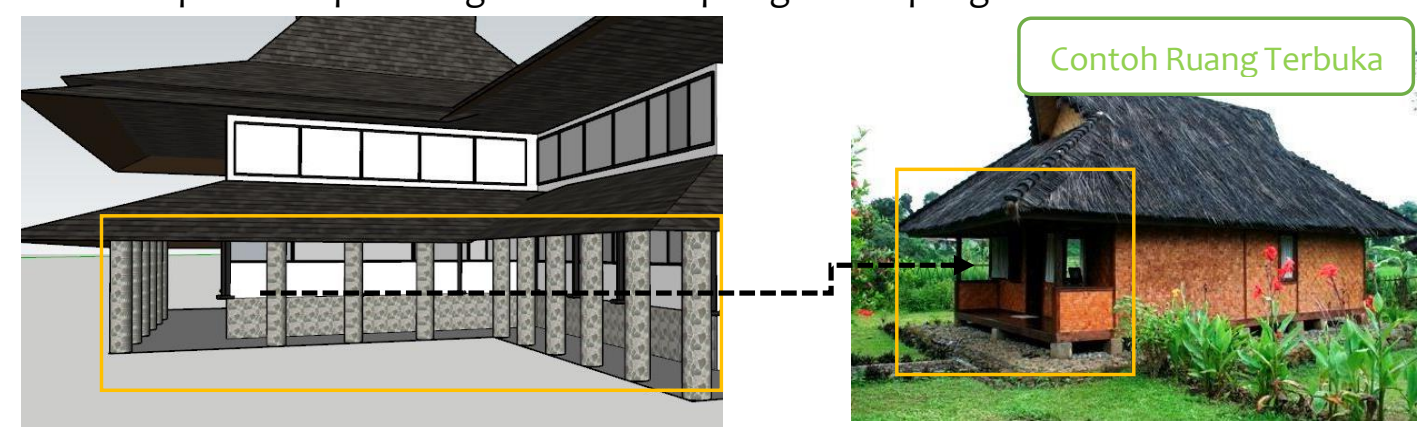

Gambar 10. Ruang Terbuka ITB

Sumber: Pribadi, https://edesainminimalis.com, 2020 
Dapat disimpulkan berdasarkan pembahasan di atas terhadap gedung Aula ITB bahwa elemen bangunan ini tidak sepenuhnya telah merespon terhadap iklim. Dari ketiga kriteria, satu diantaranya tidak terpenuhi.

a) Bagian jendela tidak menjorok ke dalam sehingga tidak tanggap terhadap iklim

b) Bagian tritisan telah menaungi badan bangunan sehingga tanggap terhadap iklim

c) Adanya ruangan bebas dinding (terbuka) pada bagian teras bangunan sehingga tanggap terhadap iklim

\section{Memiliki Konteks Budaya Setempat}

Ciri kedaerahan pada arsitektur regionalisme berkaitan erat dengan budaya setempat. Setiap daerah pasti memiliki ciri khas kedaerahan yang berbeda-beda, salah satunya sangat lekat pada bentuk bangunan sebagai identitas budaya dalam arsitektur. Ciri khas kelokalan ini termasuk ke dalam bentuk ekspresi dari bangunan tersebut. Sampai saat ini, hal tersebut dianggap sebagai simbol atau identitas bagi masyarakat tertentu sesuai dengan daerah tinggalnya. Pada analisis berikut ini akan mengidentifikasi unsur budaya yang ada pada ketiga studi kasus yang ditunjukkan oleh bentuk atapnya.

Bagian atap pada gedung aula ITB megadaptasi dari bentuk atap tradisional Jawa Barat, yaitu rumah jolopong. Sesuai dengan lokasi ITB yang berada di daerah Jawa Barat, hal itu menjadikan sebuah ciri khas kedaerahan sunda pada bangunan ini. Atapnya berbentuk seperti pelana yang memanjang dengan menggunakan dua bidang atap. Dua bidang atap ini dipisahkan oleh jalur suhunan di tengah bangunan. Bentuk atap tradisional yang digunakan sampai saat ini tetap dipertahankan, sehingga hal ini menjadi sangat menarik dari tampilan, kaya akan nilai kebudayaan, serta menjadi ciri khas unik dari gedung-gedung yang ada di lingkungan kampus ITB.
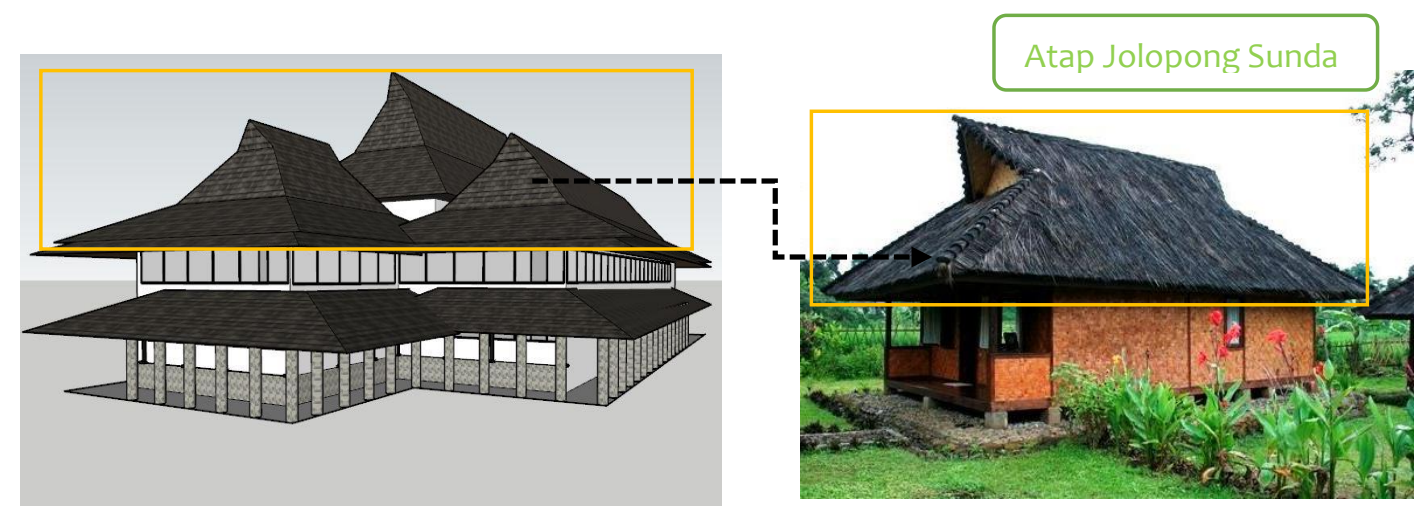

Gambar 11. Atap Jolopong ITB

Sumber: Pribadi, https://edesainminimalis.com, 2020

\section{Hasil Analisis}

Berdasarkan uraian prinsip-prinsip di atas, penilaian berdasarkan kepada keberadaan prinsipprinsip arsitektur regionalisme pada studi kasus. Tabel 1. berikut ini merupakan hasil dari penelitian studi kasus. 
32 Penerapan Konsep Arsitektur Regionalisme pada Bangunan Aula Institut Teknologi Bandung

Tabel 1. Hasil Analisis Studi Kasus (Pribadi, 2020)

\begin{tabular}{llcc}
\hline No & \multicolumn{1}{c}{ Prinsip Arsitektur Regionalisme } & $\begin{array}{c}\text { Studi } \\
\text { Kasus } \\
\text { (Aula ITB) }\end{array}$ & Keterangan \\
\hline 1 & $\begin{array}{l}\text { Material Menggunakan bahan bangunan } \\
\text { lokal dengan teknologi modern }\end{array}$ & $\checkmark$ & $\begin{array}{c}\text { Dalam keseluruhan telah } \\
\text { memenuhi ketiga kriteria } \\
\text { prinsip 1 }\end{array}$ \\
\hline $\begin{array}{l}\text { Tanggap dalam mengatasi kondisi iklim di } \\
\text { daerah setempat }\end{array}$ & $\checkmark$ & $\begin{array}{c}\text { 1 diantara 3 kriteria belum } \\
\text { memenuhi prinsip 2 }\end{array}$ \\
\hline 3 & Memiliki Konteks Budaya stempat & $\checkmark$ & $\begin{array}{c}\text { Telah memenuhi prinsip 3 } \\
\text { berupa bentuk atapnya. }\end{array}$ \\
\hline
\end{tabular}

\section{PENUTUP}

\section{Simpulan}

Dalam penelitian ini, peneliti dapat menemukan bagaimana salah satu bangunan pendidikan di Indonesia mempunyai unsur lokalitas yang masih diterapkan. Hal tersebut disesuaikan dengan wilayah di mana bangunan tersebut berada, yang sehingga termasuk ke dalam penerapan konsep arsitektur regionalisme. Berdasarkan hasil analisis, maka dapat disampaikan bahwa yang dimaksud dengan arsitektur regionalisme yaitu merupakan arsitektur yang mengedepankan penggunaan material lokal dengan teknologi modern, dapat tanggap terhadap kondisi iklim di daerah setempat, dan memiliki konteks budaya setempat. Dengan adanya penelitian ini diharapkan dapat lebih memahami prinsip-prinsip yang digunakan dalam rancangan bangunan pendidikan yang menggunakan konsep arsitektur regionalisme.

\section{Saran}

Diharapkan agar penelitian-penelitian selanjutnya akan lebih beragam lagi menentukan studi kasus yang berbeda pada bangunan-bangunan di nusantara dengan mengkaji menggunakan konsep arsitektur regionalisme.

\section{DAFTAR PUSTAKA}

Hidayatun, M. I., Prijotomo, J., \& Rachmawati, M. (2014). Arsitektur Nusantara Sebagai Dasar Pembentuk. Seminar Rumah Tradisional 2014 - Transformasi Nilai-nilai Tradisional dalam Arsitektur Masa Kini, 1-9, diakses pada 10 Oktober 2020 pukul 22.05

Melisa, \& Apritasari, Y. D. (2020). IDENTIFIKASI REGIONALISME MODERN BELITUNG SEBAGAI. Jurnal Architecture Innovation Vol 4 | No. 1 | June 2020, 46-63.

Rachmawati, M., \& Prijotomo, J. (2010). PELESTARIAN ALAM DALAM ARSITEKTUR: MASALAH DAN USULAN PEMECAHANNYA. Jurnal Bumi Lestari, Volume 10 No. 2, Agustus 2010. hlm. 341 - 351, 341-351.

Shobirin, A., Purnomo, A. H., \& Pitan, T. S. (2019). ARSITEKTUR REGIONALISME: PENERAPAN KONSEP ARSITEKTUR OSING PADA RANCANGAN HOTEL KONVENSI BINTANG 5. SENTHONG, Vol. 2, No.2, Juli 2019, 603-616.

Sardjono, A. B. (2011). RESPON RUMAH TRADISIONAL KUDUS TERHADAP IKLIM TROPIS. MODUL Vol.11 No.1 Januari 2011, 7-15.

Octavia, L., Prijotomo, J., \& Rachmawati, M. (2013). PERANAN MATERIAL UNTUK MEWUJUDKAN KREATIFITAS. SEMINAR NASIONAL SCAN\#4:2013, 326-33 


\section{Daftar Internet}

- Google Maps, https://www.google.co.id, diakses Oktober 2020

- http://www.math.itb.ac.id, diakses Oktober 2020

- https://arafuru.com, diakses November 2020

- https://www.arsigriya.com/, diakses November 2020

- http://jagobangunan.com/, diakses Desember 2020

- https://edesainminimalis.com/, diakses Desember 2020 